\title{
Sosialisasi Pembuatan Sabun Melalui Kegiatan Pelatihan Di Dusun Nampes Desa Baturetno Kecamatan Singosari Kabupaten Malang
}

\author{
Dayal Gustopo Setiadjit ${ }^{1}$, Ida Bagus Suardika ${ }^{2}$, Ady Utomo ${ }^{3}$ \\ ${ }^{1,2}$ Teknik Industri, ITN-Malang \\ ${ }^{3}$ Teknik Sipil, ITN-Malang \\ E-mail : dayal_gustopo@lecturer.itn.ac.id
}

\begin{abstract}
Abstrak
Peluang pemenuhan kebutuhan sehari-hari di masyarakat untuk produk pembersih (sabun) sesungguhnya dapat dipenuhi secara swa-sembada oleh masyarakat itu sendiri. Untuk mewujudkan kemandirian tersebut. diperlukan suatu kegiatan bagi masyarakat yang bersifat pemberdayaan pengetahuan (transfer of knowledge). Untuk keperluan tersebut diakukan kegiatan pengabdian yang bertajuk sosialisasi pembuatan sabun cair bagi masyarakat, serta merupakan salah satu bentuk pengabdian pada masyarakat yang dilakukan oleh dosen prodi teknik industri ITN-Malang. Hasil dari sosialisasi dan pelatihan tersebut, sebanyak 12 Warga dusun telah mampu untuk memproduksi sabun cair. Profil dari warga yang dilatih adalah mayoritas berprofesi sebagai buruh tani. Pada saat pelatihan masing-masing warga mampu untuk memproduksi 1 liter sabun. Beberapa metode dalam pemberian aroma wewangian turut serta di terapkan dalam proses produksi sabun tersebut.
\end{abstract}

Kata kunci : kemandirian masyarakat, pengabdian, produksi

\section{Pendahuluan}

Kebersihan merupakan suatu hal yang penting dalam kehidupan sehari-hari manusia. Baik itu untuk kebersihan badan, kebersihan dari benda-benda yang digunakan sehari-hari.maupun kebersihan lingkungan hidup. Jika kebersihan tidak terjaga dengan baik, maka akan menjadi ancaman bagi kesehatan manusia,yang menjadi potensi menimbulkan berbagai penyakit. Sabun juga merupakan produk yang frekwensi pembeliannya relative tinggi. Baik untuk kebutuhan akan produk sabun mandi, sabun pencuci tangan, sabun untuk mencuci pakaian maupun sabun untuk mencuci kendaraan.

Pemenuhan atas kebutuhan sabun tersebut sampai saat ini telah menjadikan terdapatnya peluang untuk dilakukan pemenuhan akan produk itu secara mandiri oleh masyarakat.

Peluang begitu terbuka lebar, dikarenakan pembuatan sabun cair relatif mudah untuk dipelajari, diproduksi dan dikembangkan.

Oleh karenanya diperlukan suatu bentuk kegiatan bagi masyarakat yang bersifat transfer pengetahuan dan pendampingan oleh perguruan tinggi pada masyarakat yang menjadi sasaran program ini. Program pengabdian bagi masyarakat ini diimplementasikan pada dusun Nampes Desa Baturetno Kabupaten Malang. Kegiatan Tersebut merupakan pemberdayaaan melalui pengembangan atas keterampilan sumber daya manusia warga dusun, dicapai melalui kegiatan pelatihan produksi sabun cair. 


\section{Metode Pelaksanaan}

Program pengabdian pada masyarakat yang diimplementasikan pada masyarakat dusun Nampes di Kabupaten Malang ini merupakan kegiatan pemberdayaaan masyarakat melalui pengembangan keterampilan masyarakat dusun Tujuan yang ingin dicapai adalah kegiatan memberikan pelatihan produksi, dengan menggunakan objek adalah sabun cair.

Dengan dilaksanakan kegiatan abdimas ini maka upaya untuk melatih dan menambah keterampilan (skill) masyarakat menjadi nyata. Khalayak sasaran dalam abdimas ini adalah seluruh warga dusun Nampes Desa Baturetno kabupaten Malang. Warga dusun yang telah siap untuk menjadi peserta dalam pelatihan ini sejumlah 12 (dua belas) warga. Keduabelas warga tersebut dikelompokkan menjadi 6 (enam) kelompok peserta pelatihan. Keenam kelompok tersebut dalam pelaksanaannya juga didampingi oleh Mahasiswa dari jurusan Teknik Industri ITN-Malang. Metode yang digunakan adalah Pemberian pelatihan, pelaksanaan praktek pembuatan produk secara individu dan praktek pengemasan produk sabun cair secara kelompok.

\section{Hasil dan pembahasan}

Hasil dari kegiatan ABDIMAS yang didanai oleh LP2M-ITN Malang, melalui penugasan untuk pelaksanaan Pengabdian pada Masyarakat tahun 2017-2018 bagi dosen, dapat dilaporkan hasil sebagai berikut: Sesuai dengan target luaran, saat ini mitra (warga dusun Nampes) telah mampu untuk memproduksi sabun cair Produksi yang berhasil dibuat sejumlah 10 liter sabun cair, yang siap untuk dimasukkan ke dalam kemasan. Pada saat dilaksanakannya pelatihan peserta menginginkan produk yang telah dihasilkan tersebut untuk dibagikan pada warga RT masing- masing sebagai contoh sabun cair yang siap untuk dikonsumsi sendiri.
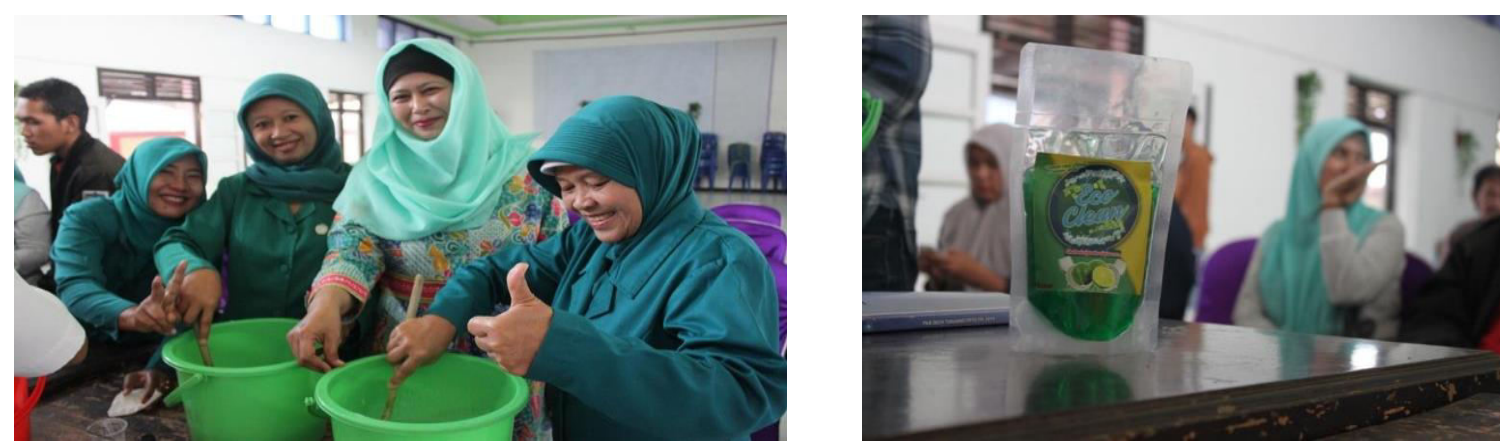

Gambar dokumentasi kegiatan di ds Tunjungtirto Kabupaten Malang

Institusi perguruan tinggi ITN-Malang yang merupakan bagian dari anggota masyarakat memiliki kepedulian untuk berperan dalam pemberdayaan ekonomi masyarakat kota maupun Kabupaten. Program pengabdian ini diharapkan menjadi bentuk nyata kerjasama antara Perguruan Tinggi dan masyarakat dalam upaya meningkatkan potensi ekonomi kerakyatan melalui implementasi transfer of knowledge pada masyarakat luas, dalam hal ini adalah teknik untuk memproduksi sabun cair.

Pada saat tutorial dan pelatihan seluruh peserta diminta untuk membuat masing- masing 5 (liter) sabun cair. Hasil Produk pelatihan tersebut selanjutnya diminta untuk dibagikan ke- seluruh warga untuk dilakukan uji pakai produk. Hasil yang diharapkan adalah diketahuinya mutu dari sabuncair tersebut berdasarkan masukan dari para pengguna sabun tersebut. Evaluasi akhir adalah pemberian tugas pada peserta pelatihan untuk memasarkan produknya pada seluruh warga di dusun Nampes. Apabila 50\% peserta pelatihan mampu dan berhasil menjual produk sabun cair tersebut, maka kegiatan pelatihan pembuatan sabun cair ini dikatakan berhasil 


\section{Kesimpulan}

Pelatihan pembuatan sabun cair telah berhasil dilaksanakan. Output dari pelatihan ini berupa produk sabun yang dikemas dalam kemasan plastik. Hasil lainnya adalah didapatnya pengetahuan (knowledge) mengenai pembuatan sabun berikut praktek yang telah dilakukan oleh warga desa. Hasil Pelatihan ini bisa disosialisasi kepada seluruh warga desa yang lain, utamanya bagi warga yang tertarik pada produk sabun cair ini untuk dijadikan peluang usaha. Pelatihan untuk wirausaha dibidang produk sabun cair dirasa juga perlu di lakukan pada program pengabdian selanjutnya.

\section{Referensi}

[1] Small Business Management, an entrepreneurial emphasis, $11^{\text {th }}$ Ed, Justin G.Longenecker, Carlos W Moore, J William Petty, Baylor University, Thomson Learning Asia.

[2] Panduan pelaksanaan Penelitian dan Abdimas ITN-Malang 